\title{
Scheffler's autopsy of poverty in the biblical text: Critiquing land expropriation as an elitist project
}

\begin{tabular}{|c|c|}
\hline \multicolumn{2}{|c|}{$\begin{array}{l}\text { Author: } \\
\text { Temba T. Rugwiji }{ }^{1} \text { @ }\end{array}$} \\
\hline \multicolumn{2}{|c|}{$\begin{array}{l}\text { Affiliation: } \\
{ }^{1} \text { Department of Old } \\
\text { Testament Studies, Faculty } \\
\text { of Theology and Religion, } \\
\text { University of Pretoria, } \\
\text { Pretoria, South Africa }\end{array}$} \\
\hline \multicolumn{2}{|c|}{$\begin{array}{l}\text { Research Project Registration } \\
\text { Project Leader: } \\
\text { A. Groenewald } \bullet \\
\text { Project Number: } 02428024\end{array}$} \\
\hline \multicolumn{2}{|c|}{$\begin{array}{l}\text { Description: } \\
\text { Dr Rugwij is participating } \\
\text { in the research project, } \\
\text { 'Exegesis and the Theology } \\
\text { of Isaiah', directed by Prof. } \\
\text { Dr Alphonso Groenewald, } \\
\text { Department of Old Testament } \\
\text { Studies, Faculty of Theology } \\
\text { and Religion, University of } \\
\text { Pretoria. }\end{array}$} \\
\hline \multicolumn{2}{|c|}{$\begin{array}{l}\text { Corresponding author: } \\
\text { Temba Rugwiji, } \\
\text { rugwiji1964@gmail.com }\end{array}$} \\
\hline $\begin{array}{l}\text { Dates: } \\
\text { Received: } 27 \text { I } \\
\text { Accepted: } 15 \\
\text { Published: } 04\end{array}$ & $\begin{array}{l}\text { Mar. } 2018 \\
\text { lan. } 2019 \\
\text { June } 2019\end{array}$ \\
\hline \multicolumn{2}{|c|}{$\begin{array}{l}\text { How to cite this article: } \\
\text { Rugwiji, T.T., 2019, 'Scheffler's } \\
\text { autopsy of poverty in the } \\
\text { biblical text: Critiquing land } \\
\text { expropriation as an elitist } \\
\text { project', HTS Teologiese } \\
\text { Studies/Theological Studies } \\
75(3) \text {, a4991. https://doi.org/ } \\
\text { 10.4102/hts.v75i3.4991 }\end{array}$} \\
\hline \multicolumn{2}{|c|}{$\begin{array}{l}\text { Copyright: } \\
\text { (C) 2019. The Authors. } \\
\text { Licensee: AOSIS. This work } \\
\text { is licensed under the } \\
\text { Creative Commons } \\
\text { Attribution License. }\end{array}$} \\
\hline \multicolumn{2}{|l|}{ Read online: } \\
\hline 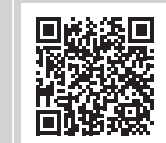 & $\begin{array}{l}\text { Scan this QR } \\
\text { code with your } \\
\text { smart phone or } \\
\text { mobile device } \\
\text { to read online. }\end{array}$ \\
\hline
\end{tabular}

Author:

Affiliation

${ }^{1}$ Department of Old of Theology and Religion, University of Pretoria, Pretoria, South Africa

Project Leader:

A. Groenewald (10

Project Number: 02428024

Description:

'Exegesis and the Theology of Isaiah', directed by Prof. Dr Alphonso Groenewald Department of Old Testament Studies, Faculty of Theology and Religion, University of

Corresponding author: Temba Rugwiji,

Dates:

Received: 27 Mar. 2018 Accepted: 15 Jan. 2019

How to cite this article: Rugwiji, T.T., 2019, 'Scheffler's autopsy of poverty in the biblical text: Critiquing land expropriation as an elitist project', HTS Teologiese Studies/Theological Studies 75(3), a4991. https://doi.org/

Licensee: AOSIS. This work

is licensed under the

Creative Commons

Attribution License.

Read online: code with you mobile device to read online.
The theme of poverty has recently dominated various scholarly platforms, including academic presentations and public debates. Nevertheless, it has emerged that the rhetoric about poverty reduction seems to be the project of the elite who apparently write and speak on behalf of the poor. The plight of the majority of the poor is problematised so that transformation is superficially democratised with the ultimate aim of benefitting the elite. The present study reflects on Eben Scheffler's contributions on poverty and the poor in the Old Testament books of the Pentateuch, the Psalms and the Proverbs. Although this study refers to Scheffler's other works on poverty from time to time, particular attention is paid to four of them, namely, (1) 'The poor in the Psalms: A variety of views'; (2) 'Of poverty prevention in the Pentateuch as a continuing contemporary challenge'; (3) 'Poverty in the Book of Proverbs: Looking from above'; (4) 'Pleading poverty (or identifying with the poor for selfish reasons): On the ideology of Psalm 109'. Scheffler points out that it was the ancient Israelite elite who played the role of writing and speaking on behalf of the poor. It is essential to note that Scheffler's thrust is not an appropriation exercise, although in some places he makes reference to the 'contemporary world'. Thus, the present study attempts to explore the land debate in our contemporary world, with a special focus on South Africa's (SA) land expropriation without compensation (LEWIC) debate and the foiled fast-track land reform programme in Zimbabwe, as elitist projects. The Zimbabwean Fast-Track Land Reform Programme (FTLRP) was a prototype of LEWIC in SA. It is argued that the poor rural communities in Zimbabwe continue to languish in poverty in a country endowed with abundant natural resources, including land. The study argues that land allocation in Zimbabwe benefitted the elite.

Keywords: Poverty; Poverty reduction; Old Testament; Pentateuch; Psalms; Proverbs; Agriculture; Land expropriation.

\section{Introduction}

When he [Jesus] finished speaking, he said to Simon: 'Put out into the deep waters, and let down the nets for a catch'. Simon answered: 'Master, we've worked hard all night and haven't caught anything; but because you say so, I will let down the nets'. When they had done so, they caught such a large number of fish that their nets began to break. (Lk 5:4-6; NIV) ${ }^{1}$

Recent scholarship (see, e.g., Anger 2010:138) has chronicled that poverty is not new, but at each mention it stirs a lot of misgiving. The above assertion is made in light of the fact that poverty has a very devastating influence on its victim. The continent of Africa is not only characterised by poverty, but also plagued by sociopolitical crises and human rights abuses which further exacerbate poverty. Thus, Abioje (2010:789) could not have said it better to articulate the following, "The continent of Africa is perceived as plagued by corrupt and selfish leaders who propagate widespread poverty, in spite of the abundant human and material resources in many African countries'. Abioje's observation had earlier on been presumed by Turaki (1997:1) who has since said, 'Lack of moral will and ethical strength by the leadership in Africa has been identified as the most serious issue and problem facing Africa today'. Although 'poverty is more likely to receive attention in religion than in philosophy' (Scheffler 2012:483), poverty, particularly in subSaharan Africa, is a reality especially when one looks at the presenting situation from an 'insider's perspective'. ${ }^{2}$ Admittedly, various layers of the causes of poverty have been put forward by scholars, such as Le Roux (1996:66-67, cited in Scheffler 2012:485), that the poor were responsible for their own situation by being lazy or idle. However, in numerous instances the Old Testament

\footnotetext{
1.The present contribution is dedicated to Eben Scheffler. Personally, i highly regard Scheffler as a seasoned scholar. Scheffler's scholarship has had a positive impact on my own writings. On an individual level, Scheffler has opened some passageways in my career as a scholar.
} 2.The author is familiar with the Zimbabwean situation.

Note: The collection entitled 'Eben Scheffler Festschrift', sub-edited by Jurie H. le Roux (University of Pretoria) and Christo Lombaard (University of South Africa). 
itself makes mention of the fact that poverty among communities was exacerbated by greed, corruption and fraud by the ruling elite (e.g. Neh 5:1), typical of what characterises the postmodern African leadership (Mills 2010:3). About the post-exilic Judean communities, it is stated that the previous governors were not only greedy and selfish by keeping the food they received from the government, but they also demanded from the people 'forty shekels of silver ... in addition to food and wine' (Neh 5:15; Rugwiji 2017:5-6).

Meanwhile, what is emerging from Scheffler's discussions in general is that the poverty debate in the books of the Pentateuch, Psalms and Proverbs was problematised by people in positions of influence. Scheffler (2015) maintains:

The Hebrew Bible often refers to poverty in its most basic form (material destitution), but if one compares it with other issues, references are fairly few and far between. This may be because the Bible was not written by extremely poor people but by the elite. The fact that the Bible was written by the elite gives significance to the fact that positive references are made to the poor. (p. 3)

Understandably, Scheffler's works are not precisely inclined towards an appropriation project, although such a thrust is apparent in numerous places, for example, Mother Theresa of Albania whose individual efforts were inclined towards helping the poor (Scheffler 2011:129). Scheffler further writes:

Since all Christians are addressed by the Jesus story there exist many untold stories of individual charity to the poor that could never be measured, but should never be underestimate'. (p. 129)

The aim of the present study is not to critique Scheffler's autopsy of poverty in the biblical books of the Pentateuch, Psalms and Proverbs. The study is an appreciation of the author's standpoint in which poverty and poverty reduction are articulated from a biblical perspective. Two critical themes are drawn from Scheffler's explanation about poverty reduction which informs the present investigation: (1) concern for the poor, hence poverty reduction, and (2) the elite writing and speaking on behalf of the poor. The present discourse complements what has been foregrounded by Scheffler with particular focus on 'appropriation' (see definition below) in view of poverty and land expropriation in South Africa (SA) and Zimbabwe, respectively. It is argued that local communities continue to endure poverty in a country endowed with various natural resources. The major causes of such a scenario are corruption and fraud by the ruling elite. The underlying objective of this study is to sensitise the broader readership that although an increase in players in the agricultural sector has potential of maximising agricultural production and economic development when utilised productively, land expropriation itself will not guarantee poverty reduction. In Zimbabwe, for example, the land issue was accelerated by the ruling elite for political mileage following dwindling numbers of party supporters who had since joined the Movement for Democratic Change (MDC) when the opposition party was formed in September 1999 (see Rugwiji 2017:16). In my opinion, the African National Congress (ANC) are taking the route of the ZANU-PF government ahead of SA's elections in 2019. In both cases, the strategy of using the agrarian reform is intended to keep revolutionary movements in power.

\section{Definitions}

\section{Poverty}

Many people and organisations have defined poverty in various ways. Hence, Kankwanda (2002:3) was right to note the following: 'Poverty is a multidimensional phenomenon influenced by a wide of range of factors which include: lack of access to income earning and productive activities and essential social services'. According to Addae-Korankye (2014):

In its extreme form, poverty refers to lack of basic human needs to sustain as useful and working efficiency such as adequate and nutritious food, clothing, housing, clean water and health services. (p. 147)

In addition, the World Bank (2005) also defines poverty as 'hunger, lack of shelter, and being sick and unable to see the doctor'. Meanwhile, United Nations Human Development (1998) defines poverty as 'a complex phenomenon that generally refers to inadequacy of resources and deprivation of choices that would enable people to enjoy descent living conditions'. For Narayan et al. (2000), 'The poor themselves see powerlessness and voicelessness as key aspects of their poverty'. Scheffler (2011) explains as follows:

There is also reasonable consensus that the terms usually used for 'poor' in the Hebrew Bible (dal, ani, ebjon and dasj) usually refer to 'the poor' as those in society who are materially destitute, not having the basic means for survival. (p. 193)

\section{Poverty reduction}

In a number of places, the phrase poverty reduction is preferable ahead of poverty eradication. This is particularly so because 'poverty reduction is more plausible than poverty eradication from both a practical social perspective as well as a biblical perspective' (Wax 2013:226). Wax further observes, 'We continue to be hoodwinked by politicians who promise the eradication of poverty as a grand ideal' (2013:226). In my view, while on the one hand poverty eradication may remain an anticipated goal over a period of time, on the other hand poverty reduction can be achieved using a short-term strategy. However, Grubb and Ryan (1999) opine as follows, 'Skills and training stimulate economic competitiveness, raise productivity and incomes, and play an important role in poverty reduction'. Thus, Wax (2013) could not have said it better to make the following affirmation:

The health of any society can therefore be determined by the extent to which it takes care of the poor in society. It is therefore the responsibility of all politicians and public servants to take a leading role in reducing levels of poverty in society. This brings the unacceptable levels of corruption into sharp focus. (p. 226)

\section{Contemporary world}

For the majority of African biblical interpreters, the biblical text is usually read in view of the immediate or presenting 
context (hence, contemporary world). Themes from the ancient Israelite tradition are interpreted from a postbiblical perspective. I would prefer to describe such an approach as 'hermeneutics of appropriation' (see Rugwiji 2013:13). In hermeneutics of appropriation, relevant themes from the ancient biblical world are appropriated in the contemporary world. For Scheffler (2013):

The term 'contemporary' in the Bible has double implications, (1) the ancient context(s) in which the biblical text(s) functioned, and (2) the present-day context in which an attempt is made to appropriate these texts and the historical constructions we make regarding them. (p. 1)

Meanwhile, Scheffler describes the approach of appropriating biblical themes in our contemporary world as a 'dialogue'. According to Scheffler (2004):

A dialogue implies that the interpreter interacts with the text as a free person: (s) he may interpret what (s) he finds useful or relevant, but also indicate what one in all honesty cannot believe anymore. (p. 668)

\section{Land in the Pentateuch, Psalms and Proverbs}

In the Pentateuch, the world and its resources are committed to humanity (Gn 1:28-29). God, as the owner of the land, 'took the man and put him in the Garden of Eden to cultivate it' (Gn 2:15) because 'he has given it to the sons of men' (Ps 115:16). Time and again, the land is portrayed as belonging to Yahweh (Gn 15:7; Lv 25:23), and that the covenant relationship between Yahweh and Israel was made through transfer of ownership from a deity to humans (Gn 12:1-3; 12:23). The land is also depicted as a 'gift of grace' (Gn 12:1-17; 4-8; Dt 9:6). Hence, every time the Israelite descendants referred to land, they did so in recognition of the exodus motif that 'the land that the Lord gave to our fathers' because the land was promised to the patriarchs: Abraham, Isaac and Jacob (Gn 12:7; 13:14-17; 15:7, 18; 17:8; 26:4; 50:24; Ex $32: 13 ;$ Dt $1: 35-36 ; 30: 5)$. In the exodus tradition, the motif of land is reaffirmed: 'I will bring you to the land which I swore to give to Abraham, Isaac and Jacob, and I will give it to you for your possession; I am the Lord' (Ex 6:8; Dt 6:10-11; Nm 33:53-54). The land given to Israel by God 'is spacious' (Ex 3:8), 'flows with milk and honey' (Dt 31:20-21; Lv 20:24) and 'is an exceedingly good land' (Nm 14:7-8).

Meanwhile, the rhetoric of land being God's domain is also mentioned in other biblical books, including prophetic literature (Jos 22:19; Hs 9:3; Jr 16:18). In the Psalms and Proverbs, it is also stated that the land belongs to God (Ps 24:1; 85:1), and it is only 'the humble will inherit the land, and will delight themselves in abundant prosperity' (Ps 37:11). In Proverbs 28:19, we read, 'Those who work their land will have abundant food, but those who chase fantasies will have their fill of poverty'. Hence, when Le Roux (1996:6667), among other scholars, sees poverty as a consequence of laziness or idleness, such a reading in Proverbs is inevitable.

Elsewhere it is stated, 'The righteous will never be rooted, but the wicked will not remain in the land' (Pr 10:3). However, keeping the land on the part of Israel was dependent upon 'Justice, and only justice, you shall purse, so that you may and occupy the land ...' (Dt 16:20). Loss of land through deportation and captivity was attributed to Israel practicing the opposite, that is, unjust practices (e.g. Dt 16:19; 2 Chr 7:14; Pr 6:16-19; 11:1; 12:22; 17:15; Ps 43:1; Is 10:1-3). The narrative of Naboth's vineyard (1 Ki 21) $)^{3}$ features as an example of injustice which the biblical text condemns, as stated in the following two verses:

The word of the Lord came to Elijah the Tishbite: 'Go down to meet Ahab king of Israel, who rules in Samaria. He is now in Naboth's vineyard, where he has gone to take possession of it. Say to him this is what the Lord says: 'Have you not murdered a man and seized his property?' Then say to him, 'This what the Lord says: In the place where dogs licked up Naboth's blood, dogs will lick up your blood - yes, yours'. (vv. 17-19)

The other theme that comes out of the biblical text is that of selling/buying of land. Although in some places in the Old Testament Israel was warned against the selling of land (Lv 25:23-28, 34), not everyone who owned land got it for free. Some individuals had to pay for it. One would buy land to cultivate it and to 'plant vineyards' (Pr 31:1). Others would buy land to use it as a burial ground. For example, Abraham bought land in Hebron (Cave of Machpelah) as a burial place for the patriarchs (and matriarchs); Abraham, Isaac, Jacob, Rebecca, Leah and Sarah were buried there (Gn 23:19; 25:9; 49:29-32; 50:13). Joseph was buried at Shechem on land which was bought by Jacob (Gn 33:18-20; Jos 24:32). One would also buy land for other uses such as pitching a tent or building a shelter (Gn 33:19). The biblical text did not condone the moving/shifting of 'ancient boundaries' (Dt 19:14; 27:17; Job 24:2; Pr 22:28; 23:10; Hs 5:10).

Shifting boundaries was an act of corruption or 'land grab'. Hence, Proverbs teaches, 'Wealth obtained by fraud dwindles' (Pr 13:11). Thus, taking someone's field and property is forbidden (Mi 2:2).

Governments in ancient near east (ANE) would also buy land from (or make compensation to) individuals whose land was negotiated for sale. For example, we read, 'So Joseph bought all the land of Egypt for Pharaoh. The Egyptians, one and all, sold their fields because the famine was too severe for them. The land became Pharaoh's' (NIV) (Gn 47:20). In this case, Pharaoh (or the government) had enough land to resettle other land seekers. Hence, Pharaoh ordered Joseph to settle Joseph's family members in Goshen (Gn 45:9-10). In the above illustration, the leadership did not have to seize land from 'Tom' to resettle 'Tim'. ${ }^{4}$

As shown in the above discussions, God owns the land and transfers ownership to humanity (Israel) whenever He chooses. Nevertheless, in Trito-Isaiah, the old covenant

3.See also a similar story about David killing Uriah (2 Sm 11-12). Although the narrative of David killing Uriah in order to take Bathsheba, Uriah's wife, has nothing to do with land possession, the underlying theme is that it is in the power of those in positions of authority (the elite) to seize even the little from those who do not have enough.

4.Just an example to illustrate a leadership of a country which confiscates property from one citizen in order to compensate another citizen. 
(even of land) which God made with Israel cannot be the thing to hold onto anymore because 'the former things will not be remembered or come to mind' (Is 65:17). There will be a new covenant, premised on 'the new heaven and the new earth' (Is 66:22).

This shift from the previous instruction to Israel had already begun to be conceptualised also in terms of circumcision in the book of Deuteronomy in which we read of the 'circumcision of the heart' (Dt 30:6).

\section{Thus, Scheffler (2004) holds this view:}

In our search for a relevant and 'Pentateuchal ethic' we can benefit from engaging in dialogue with issues raised in the Pentateuch (e.g., our general human suffering, poverty, landlessness, land exploitation, economics, exclusive nationalism and enmity, slavery - Dt 15). (p. 668)

\section{Eben Scheffler on poverty and the elite speaking for the poor}

For Scheffler (2012:480), 'The Old Testament sage argued from the viewpoint of the rich or middle class because the wisdom teachers from ancient Israel per definition belonged to that class'. Thus, Rugwiji (2013) approves:

Much of the discussion on the deportation of the Judeans focused on the depiction of the exiled elite and their experiences in Babylonia, and not so much on the poorer remnants. (p. 125)

\section{Scheffler (2012) further argues:}

The wisdom teachers of the Old Testament are therefore elitist, their wisdom pertains to the upper class, dealing with matters that concern them, their problems, how they should act (e.g., in business, political power, and sexual matters) and also how their behaviour towards poverty and the poor should or could be. Everything is said from their viewpoint and benefits themselves. The positive remarks to help the poor are not really genuine but only serve to keep the class distinctions intact (Pr 22:2: 29:13), so that they as wisdom teachers can remain in their privileged position. (p. 480)

'Because poverty in ancient Israel was regarded in a negative way', contends Scheffler (2011:485), 'one wonders whether a unitary wisdom perspective of poverty as a function of the elite's social position was at all possible'. Scheffler makes the aforementioned assertion at the backdrop of previous studies which have shown that, 'Many a war was started with the Bible in hand, and many harmful political and individual actions were taken with some sort of justification from the Bible' (2006:17). In addition, Scheffler (2011:194) reiterates, 'In wisdom literature (especially as reflected in the book of Proverbs) the poor were depicted as being responsible for their own poverty'. Meanwhile, Scheffler portrays that he counts himself as 'one who earnestly desires that the suffering of the poor should be ameliorated'. It is interesting to note that Scheffler (2011:194) recounts, 'Although the spirit is willing and the flesh weak, I think I have written enough in the past to make my sentiments clear'. In the above rhetoric which is a prototype of Jesus' statement in Gethsemane before his arrest (cf. Mt 26:40), Scheffler demonstrates not only his familiarisation with the New Testament narrative, but also an acknowledgement (and rightly so!) of his previous contributions on poverty reduction and scholarship in general. As Scheffler (2011:195) opines, 'In the wider ancient Near Eastern world it was anticipated that the king should care for the poor (see for example poetry in Ps 7)'. When Scheffler (2011:196) makes the following assertion, 'Yahweh is also interpreted as the 'unjust crusher' of the pious poor', I began to realise that Bible believers and parishioners at large are being misrepresented by sermons which always portray God in a positive light. Thus, Scheffler (2011:194) confirms, 'If one investigates the biblical material, especially the psalms, one should as a Bible scholar be honest and not make the text say what it does not say'. Scheffler's (2011) comments are also stimulating as in the following statement:

In our contemporary world (and SA is no exception!), it often occurs that the elite (leaders and other prominent figures) of liberated peoples of the third world still regard themselves as poor or 'from previously disadvantaged groups' in order to receive material benefits and special positions to enrich themselves. Often these already empowered people exhibit no desire to act on behalf of the really poor, those 'untouchables' who experience hunger on a daily basis. A critical reading of Psalm 109 can assist in exposing their ideology. (p. 205)

\section{Scheffler (2013) reaffirms:}

The biblical text originated and initially functioned in the circle of the elite, arguing that the Pentateuch was not written by poor people but the religious elite of ancient Israel, who constituted only a small minority of the population. (pp. 9-10)

In addition, Scheffler's attestation can be situated within a broader framework of the Old Testament scholarship on poverty and the elite. For example, one would read Scheffler's contestation with a hindsight of Gottwald's (1993) own contribution:

The dominant tribute-imposing class consisted of the political elite - native and/or foreign - and their administrative, religious, and military retainers, together with the landholding, merchant, and small manufacturing elites who benefited from state power. (p. 6)

Gottwald (1993:8) further states, 'Over the course of monarchic history, we detect rising and falling sequences of state power, both in its relation to foreign powers and in its relation to native non-governmental elites'. Gottwald articulates as follows:

Information from the book of Kings, coupled with the known deportation policies of ancient Near Eastern empires, makes it clear that the Babylonian exiles addressed by Deutero-Isaiah were members and descendants of the former Judahite political elite, and that Deutero-Isaiah was on the leadership of the restored Judah. The social class addressed by the prophet is conceived as a reformed and purged political elite with professional competency and a renewed sense of mission, which it can successfully carry out if it is willing to follow Deutero-Isaiah's lead. (p. 16)

Scheffler's argument for the elite is further prompted by the Old Testament ideology of the covenant which presents the notion that the deportation of the Judeans portrayed the 
exiles as a covenant people, hence the following argument, 'The narrative was written from the Diaspora elite perspective' (Cataldo 2009:71). Equally subservient to Scheffler's stance about the elite speaking for the poor is Vanderhooft (2000:6) who makes the following supposition, 'The Babylonian Empire focused on the domination and exploitation of nonBabylonian populations for the benefit of the ruling elite'. Holmgren (1987) also complements the same stance, 'Those who oppressed the poor were Jewish governors appointed by Persia, the diasporic 'elite' who came along with some poor people from exile'. With reference to the Judean returnees from exile, Rugwiji (2013:120) does not present his case differently to maintain as follows, 'It is not likely that the remnants proper would oppress the arriving exilic "elite"', which Kessler (2007:142) prefers to call the geographically transplanted elite'. When Scheffler (2001:142) had previously asserted this, 'It was the peasants and the disadvantaged people who bore the brunt of exploitation through payment of taxes', one would take it as an expression which purports that rural communities, who usually are poor, were taken advantage of by the ruling elite to further deprive the marginalised groups. Added to it, one would regard Scheffler's assertion as confirmed by Cataldo (2009:172) who noted, 'Poverty was exacerbated by oppression from the priests and the Judean governors who served as "rulers" for the Persian provincial administration'. Thus, 'The ordinary and rural communities from among the returnees were also oppressed by both the Persian authorities and the elite group of the Judean governors who were appointed by Persia' (Rugwiji 2013:128).

\section{Poverty reduction as a contemporary challenge ${ }^{5}$}

At the beginning of this article, I alluded to the fact that Scheffler's analysis of poverty in the biblical books of Pentateuch, Psalms and Proverbs was not meant to problematise precisely an appropriation thrust.

However, some glimpses of appropriation in Scheffler's contributions cannot go unnoticed, and the current debate would like to utilise them in a positive way. Although 'poverty' remains the focal point drawn from among the concepts raised by Scheffler, the author is also keen to dialogue with Scheffler on themes such as the elite and the land. The readership, which is familiar with a hermeneutical persuasion, would appreciate Scheffler's (2015) solidarity with the poor such as expressed in the following account:

One considers people who have no voice themselves, people who are not represented in the debate. For the real poor are infants who cannot yet speak and who die of hunger every day with desperate mothers unable to feed them. Twenty to thirty thousand such people die in the world every day. And it is real. One can just turn on the news and watch pictures on the Ebola-stricken areas of Liberia, but you can also enter any squatter camp in SA. (p. 1)

Scheffler (2013:4) makes mention of the exodus tradition and land promises when he refers to spacious land (Ex 3:5-7). According to Scheffler (2013):

5.For a detailed description of the phrase, see Scheffler (2013:1-14)
The context is clearly not urban, but that of peasants of the land fighting for their basic existence (the extended cultural community). The liberation experienced in the Exodus forms the angle from which poverty should be judged. (p. 5)

Gottwald (1993:5) says, 'The productive processes that generated wealth and power in the biblical world centred on land and were capitalists'. In addition, Gottwald states, 'The vast majority of people produced and other life processes from the earth, working in the household and village teams' (1993:5).

When Scheffler (2011:197) writes, 'Those concerned for the poor are promised help when they themselves would require it (Ps 41:1-3)', one is reminded about fundamentalism largely adopted by the modern Christian church, commonly known as Pentecostal churches (Togarasei 2015:56-66). In the Pentecostal movement, congregants are urged to give so that they will prosper, hence the coined phrase 'prosperity Gospel' (see, e.g., Gbote \& Kgatla 2014:1-10). Scheffler (2011) reaffirms:

In Psalm 112, the pious person who gives generously to the needy is praised and pronounced blessed and in Psalm 74:19-21 the poor and the needy people are prayed for. (p. 197)

Interestingly, Scheffler (2011:196) also addresses the question of Zion theology, 'Yahweh will rule through a descendant of David (Ps 132:11, 14)'. In my view, Zion theology predominantly cuts across the teaching of the Hebrew Bible in which the addressees are made to anticipate the emergence of an individual to be king, who is expected not precisely to address spiritual matters, but material complexities in a real, physical world. Elsewhere, this 'Zion theology' is explored, however, as 'Messianic expectation/hope' (e.g. Clements 1989:3-19). Looking at it from that perspective, other Bible readers elsewhere may not be in the wrong when they look at their own suffering against the backdrop of the promises of the ancient biblical text to be fulfilled in their context(s), even in a postbiblical world.

Among academics and theologians, the debate on poverty and the poor has emerged as the epicentre of their contestations. The role of faith-based organisations (FBOs) towards poverty reduction cannot be overemphasised. Hence, Wermter (2005) draws himself into making the following conclusion:

The church which is convinced of the value and importance of every human being must speak up for those normally neglected and considered not important in the power struggle: the poor, the marginalised and the disadvantage. (p. 11)

Earlier on, Canaan Banana had also given the following opinion, 'Christ associated himself with the downtrodden and those despised by society' (1991:9). In the same vein, reference is also made to Crystal's (1990:702) contribution which advanced this view, 'Liberation theology which stresses on the role and mission of the church to the poor and the oppressed in society, of which Christ is understood as the 
liberator'. Banks (1972) seems to regard those who oppress the poor as the 'agents' of the devil. According to Banks (1972:87), 'The Evangelical recognises that the world system is in the lap of the devil, and that injustice, war, poverty and prejudice are all parts of the system'. Bonino was not unaware of the dictates of God towards the poor when he said, 'God is clearly and unequivocally on the side of the poor' (1984:105). Sobrino (1984:105) who supports Bonino also affirms, 'The poor are the authentic theological source of understanding truth and practice'.

Warmback proposes for 'a theology that takes seriously the task of poverty eradication while at the same time respects the integrity of the natural environment' (2000:166). Warmback further remarked that he has a 'strong interest in theology and the environment and the church's role in society' (2000:167). Wax (2013:31) concurs, ‘Usually poverty originated from unjust social structures'. According to Kiogora (1998):

The phrase 'preferential option for the poor' was coined to indicate one of the most important hermeneutical keys in the Theology of Liberation. God, the theologians insisted, being by nature just and merciful, is more inclined to hear the cry of the poor. Moreover, by virtue of their poverty, the poor are the weak in society, and God prefers to operate in the world from the perspective of the weak, the poor, or those at the periphery of human made 'centres'. Anything that dehumanizes persons and poverty does that - distorts God's image in human beings. (p. 340)

Elsewhere, when Dietrich Bonhoeffer (1967:361) stated, 'God can only help the suffering', he presupposed a consciousness which within 20 years fragmented to attract pro-poor individuals such as Allan Boesak (1981:19) who reverberated as follows, 'Yahweh comes openly to the aid of his downtrodden people for all the world to see and to know that he lives with and for his people'. Boesak (1981) adds, 'Yahweh is the liberator of the oppressed and the one that uprightly defends the poorest, who saves the children of those in need and crushes the one that oppresses (Ps 72)'. According to Boesak, 'Yahweh demands justice not only from the Pharaoh who oppressed Israel, but also from the rich and the powerful within Israel who will not give justice to the poor' (1981:19). Meanwhile, Rugwiji (2012) also confirms:

The fact that prophets emerged onto the scene and stood up against injustice perpetrated upon the poor and the oppressed by the kings, renders enough ground to suggest that the exodus tradition inspired people to challenge these evils on behalf of God. (p. 53)

Hence, thinking of the exodus, one is continuously presented with the elite playing a role in socio-religious matters in ancient Israel which Eben Scheffler's conversations have consistently foregrounded. Henceforth, when Rugwiji makes the following contribution, 'The livelihood of the lessprivileged is dependent upon those who hold economic power' (2012:89), it is in solidarity with Scheffler's position that the elite always take a centre stage in numerous discourses on poverty and poverty reduction.

\section{Land expropriation in South Africa as an elitist project}

In its general usage, the phrase 'land expropriation' refers to the recovery of that which was previously seized from the original owner(s). The biblical text does not make reference to this phrase, although some claims to land rights are made. For example, talking of the Judean post-exilic society which had lost land to the ruling elite, Nehemiah 'challenged the leadership to give back to the poor people their fields, vineyards, olive orchards, and their houses, as well as reimburse the interest they had charged on money, grain, wine, and oil' (Neh 5:3; see Rugwiji 2017:5). In the modern-day sense, Land Expropriation without Compensation (LEWIC), for example, in SA or Zimbabwe's Fast-Track Land Reform Programme (FTLRP), can be disastrous to the entire economy of the country. ${ }^{6}$ Meanwhile, poverty in SA is complex. The complexity is not compounded necessarily by the prevalence of the poor countrywide, but more so by two critical issues: (1) the strategy chosen towards poverty reduction and (2) insincerity on the part of the elite speaking for the poor. The former South African President Thabo Mbeki (2006) might not have been in the wrong to remark that:

Endemic and widespread poverty continues to disfigure the face of our country. It will always be impossible for us to say that we have restored the dignity of all our people as long as this situation persists. For this reason, the struggle to eradicate poverty has been and will continue to be a cornerstone of the national effort to build the SA. (n.p.)

However, one usually hears the voice of the affluent clamouring for land. This status quo has inevitably attracted some criticism by scholars such as Branson (2016):

The apparent bias in favour of a relatively small elite was further replicated in the Recapitalization and Development Policy Programme (Recap) in 2014, with its insistence on land reform beneficiaries having business plans and mentors from the private sector. (n.p.)

Meanwhile, clamouring for land reform towards poverty reduction in SA is noble. However, numerous questions have been asked about the legitimacy of the programme in which largely the elite seem to have a stake. Hence, Branson (2016) says, 'Aspirant black commercial farmers have taken government grants and bank loans, and hired consultants, but have done little to alter the structural imbalance in the agrarian economy'. Nevertheless, SA is determined towards LEWIC. Bekezela Phakathi reports that the ANC President Cyril Ramaphosa said:

LEWIC should be implemented in a way that increases agricultural production, improves food security and ensures that land is returned to those from whom it was taken under colonialism and apartheid. (Business Day, 16 February 2018)

Ramaphosa 'is hopeful that land reform can be sustainable and beneficial to the country' (Mbabama 2018). Although on

6.The transfer of all land owned by white commercial farmers to the black people has been criticized as the cause of the economic meltdown in Zimbabwe. For further been criticized as the cause of the economic meltdown in Zimbabw
reading, see Ndlovu-Gatsheni (2009:1140) and Rugwiji (2017:16). 
the one hand SA is geared towards LEWIC, on the other hand, in a bid to right the wrongs of the past, Zimbabwe is on a paradigm shift of correcting the previous mistakes by recalling former commercial farmers to compensate them for their farms expropriated in the controversial FTLRP. One wonders whether Chilunjika and Uwizeyimana had the idea of such a shift in mind when they published their 'Shifts in the Zimbabwean land reform discourse from 1980 to the present $^{\prime}$ (2015:130-144). Whether SA's land expropriation will succeed is still to be seen. Meanwhile, one would prospect that sometimes people's ingenuous solutions to presenting problems may end up with devastating consequences which will last for a lifetime. Zimbabwe is a practical example! Now that others are beginning to comment on SA's land policy, the few who are influencing LEWIC and when it succeeds will not do so without some warning against its implementation. Yolisa Mfaise, for example, declares, 'AgriSA has repeatedly cautioned about the lack of post settlement support and stressed the importance of sustainable settlement models' (2018:3). Although 'in certain circumstances the court in SA may acknowledge LEWIC' (Van der Walt 2005; see Du Plessis 2009:105), individuals occupying influential portfolios may not want to be criticised as being on the bandwagon to the downturn of agriculture as a productive sector. This is usually predictable when people do not project the negative impact of the implementation of LEWIC to the economy as a whole. Hence, SA may need to be decisive in predetermining its preparedness in response to the consequences of LEWIC not only to SA, but also to the SADC region as a whole.

Currently, SA stands as the third largest economy in Africa after Egypt; Nigeria commands the top place (Sega \& Lekaba 2014:1). Other economies in SADC (e.g. Zimbabwe and Mozambique) are battling because of various micro- and macroeconomic factors. ${ }^{7}$ Statistics South Africa (2017:1) estimates the mid-year population at 56.52 million. If SA's agricultural sector ceases to bankroll the country's food industry (such as what happened in Zimbabwe for close to 2 decades $^{8}$ ), SADC might find itself in a succession of another precarious situation to accommodate immigrants as well as to salvage the food crises because of a decrease in agricultural production against the increase in the numbers of consumers. Thus, poverty in SADC countries will continue deepening. What this entails is that the noble idea of striving towards poverty reduction now tends not only to exacerbate poverty, but also to actually invite starvation, malnutrition and deaths. Meanwhile, Msaise (2018:3) has warned, 'The LEWIC resolution has the potential to delay, rather than speed up land reform as land owners will likely litigate in order to protect their property and property rights'. Having noted the above, one would also acknowledge Walker and Cousins' (2015:8) affirmative stance (cited in Branson 2016), 'Current policies are entrenching [the] legacy of exclusion, by bolstering the power of a small elite at the expense of the majority of rural South Africans'.

7.The Zimbabwean situation has been discussed variously by scholars. This study will highlight Zimbabwe's economic situation after FTLRP which commenced in the late 1990s.

8.The Zimbabwean economic situation is also addressed in this investigation.

\section{Land acquisition in Zimbabwe as an elitist project}

Rugwiji (2013) posits this opinion, 'In Zimbabwe, poverty has been a subject of concern among most communities'. Hence, Kunhiyop (2008:138) follows up, 'From the tip of the horn of Africa to Namibia, poverty is pervasive'. Much of the poverty that rural communities in Zimbabwe endure is attributed to unproductive pieces of land. Although it was promised that:

commercial farms were seized to resettle landless people in Zimbabwe, many landless people have either been resettled on unproductive pieces of land or did not obtain land at all, while the ruling elite in ZANU-PF shared among themselves many hectares of fertile land. (Rugwiji 2013:129)

The ruling elite take advantage of poor citizens by constantly pointing to the impact of colonialism and inequality with a special focus on land to make people believe that acceleration of land expropriation would address their poverty situation. Although this could be true to some extent, it is not always the case. Zimbabwe, as a case study, has demonstrated that land expropriation is not feasible. Hence, Rugwiji (2013) claims:

African countries emerging from decades of colonial subjugation or ethnic conflict, have rekindled a new wave of enslavement and oppression which has seen the exacerbation of poverty on the majority of ordinary people. (p. 31)

SA is no exception. It is Mugabe's policy of political survival, characterised by disregard for the political rights and economic welfare of fellow Zimbabweans which predictably led to the economic and political ruin that the country has experienced since 2000 (Zimudzi 2012:508). Chidoko et al. (2011) have chronicled:

Zimbabwe is a landlocked Southern African country with a land area of $390757 \mathrm{~km}^{2}$ of which $85 \%$ is agricultural land and the remaining comprises national parks, state forests and urban land. (p. 1)

The following statement by Masiiwa (2006) will presage the argument surrounding land acquisition in Zimbabwe:

Towards the end of the first decade, the government socialist rhetoric was thawing down in favour of socialist principles. The adoption of the Economic Structural Adjustment Programme (ESAP) in 1990 was a fundamental development that shaped the agrarian reform. This in turn saw the emergence of the black elite, which was eager to gain from the system ahead of the landless peasants. During the period, the Commercial Farmers' Union opened up its membership to about 300 new black farmers including 10 cabinet members. Its position of influence thus increased from purely white owned body to serving interests of the black elite class who, like white farmers, were keen to promote their individual interests at the expense of the landless. (p. 6)

The Zimbabwe Human Rights (ZHR) NGO Forum (2010:5) speaks, 'Since 2000, ZANU-PF has capitalized on the land reform for political mileage'. The Forum chronicles that in the 2000 parliamentary elections, ZANU-PF campaigned with the slogan, 'Land is the Economy and the Economy is 
the Land'. The Forum further writes that in the 2008 elections the ZANU-PF manifesto was ' $100 \%$ Total Empowerment and Independence' (2010:5), thus using the land issue to achieve their political agenda. Chinake (1997) concurs:

The vision of an egalitarian Zimbabwean society by the year 2000 envisaged after Independence in 1980 has been blurred by the failure of development programmes to alleviate poverty and reduce inequalities, particularly in the country's rural areas. As a result of market-based economic reforms, drought and other interplaying factors, the poor and disadvantaged sections of the population have become further marginalised, thus making development efforts futile. (p. 39)

\section{Chinake (1997) further proposes the following:}

If all these strategies are fostered with political commitment and sincerity there is a greater chance for the poor to visualise a better future and enjoy the fruits of an independent Zimbabwe. The key element, however, is for all Zimbabweans to be seriously dedicated to eradicating poverty. (p. 49)

Hence, Kamidza (1996) mourns that the story of 'peoplebased' development in Zimbabwe can safely be equated to a 'development crisis', especially after 16 years of costly failures to reduce poverty. Rugwiji (2013:145) also makes this report, "The plight of the poor in Zimbabwe is exacerbated by the fact that those in positions of leadership do little or nothing about the circumstances of poverty-stricken communities'. Thus, it is affirmed that:

If land redistribution was undertaken in an orderly manner, deserving citizens would have been allocated with fare shares of pieces of land as opposed to the elite in government hijacking it. (Rugwiji 2017:19)

To that effect, it was not an overstatement for Kriger to write the following:

The guerrilla veterans of the Zimbabwe liberation war played a prominent role in intimidating members of the opposition MDC and in spearheading the invasions that drove white farmers from the land and led to the chaotic 'fast-track' land distribution reform exercise, popularly known as the Third Chimurenga. (2003:407)

The narrative of the elite versus the commoners is elaborated by Rugwiji (2017) in the following passage:

The Zimbabwean political leadership, community leaders and religious leaders should demilitarise the land reform. As it is now, most leaders have more than one farm. The majority of the rural people who deserved land did not get it while the 'elite' wrestled among themselves to acquire land. Cabinet Ministers and City Council's officials have showered themselves with farms that they are not using. If the Zimbabwean government is serious about alleviating poverty among its citizens land allocation priorities should be given to the landless people, most of whom continue to cultivate on overused and unproductive soil. (p. 19)

Furthermore, Rugwiji (2017) orates that:

The majority of Zimbabwean poor lives in rural areas and land resettlement should have accounted for this category of beneficiaries first. To the contrary, land is allocated either on the basis of political belonging or ethnicity. (p. 19)

\section{Rugwiji (2017) maintains:}

The ruling party ZANU-PF has since employed the ideology of exclusion and inclusion in order to divide and rule as a strategy towards a government composed largely of either war veterans or Shona-dominated ruling elite, while the minorities and nonwar veterans are excluded. (p. 23)

Therefore, the officials administering land distribution are towing this ideology. 'Those who benefitted from the previous fast-track land reform', opined Rugwiji (2013):

largely comprised the elite in government or those whose credentials were traced to the liberation struggle, while the majority, whose means of survival derived from farming, lost it all when the farming activities were disrupted by farm invasions. (p. 225)

\section{Conclusion}

This study has succeeded in discussing land and poverty reduction in the SADC region (SA and Zimbabwe) in dialogue with Eben Scheffler's discourses on poverty and poverty reduction in view of his readings in the biblical books of the Pentateuch, Psalms and Proverbs. Although it is not possible to dialogue with all contributions on poverty by Scheffler, at least an effort was made to follow the veteran scholar's arguments.

Although Scheffler did not discuss the land issue as a strategy towards poverty reduction, this article explored the land question because in both SA and Zimbabwe agriculture plays a key role in food production as well as Gross Domestic Product (GDP). In my reading of the Pentateuch, Psalms and Proverbs, I see land as a resource being the epicentre of the survival of ancient Israelite communities as it is among our modern postbiblical societies. When I present my argument of agriculture as a key strategy towards poverty reduction in our contemporary world, I am appropriating the biblical view of land in both SA and Zimbabwean contexts. For some readers, this study might appear as being pro-poor in essence. Although that aspect cannot be disputed to some extent, I do not subscribe to the notion of handouts as a way of helping the real poor because I take it that it has a tendency of promoting dependency syndrome. The study has argued that in both ancient Israel (as depicted in the biblical text) and the modern postbiblical world, the elite (or people in positions of power) seem to be spokespersons and the conduits through which the plight of the poor can be ameliorated. In addition to the above, a revolution which initially presented itself as targeting and benefitting the poor of our societies ends up being a preserve of the elite who were vocal about empowering the poor and the marginalised. One then wonders whether the seemingly propoor politicking was sincere in the first place. Zimbabwe was cited as an example of such a scenario where the farms seized from white commercial farmers ended up in the hands of the ruling elite, while the real landless poor continue to languish on unproductive pieces of land. The study has also explored LEWIC in SA and that the country may need to revise its land policy because the possibility of falling into the same trap as that of Zimbabwe is predictable. At least the Zimbabwean 
leadership has learned a lesson, and currently is revising the country's land policy with a view of compensating evicted commercial farmers who lost their land and property in the previous FTLRP. During the last 2 decades, SA has been a refuge to numerous immigrants from Africa, most of them Zimbabwean. The absence of economic stability in SA not only undermines all efforts towards poverty reduction in Africa, but also presents some paranoia in the context of investment.

\section{Acknowledgements Competing interests}

The author declares that he has no financial or personal relationship(s) that may have inappropriately influenced him in writing this article.

\section{References}

Abioje, P.O., 2010, 'Critical prophecy and political leadership in Biblical, African and Islamic Worldviews', KOERS 75(4), 787-810. https://doi.org/10.4102/koers.v75i4.107

Addae-Korankye, A., 2014, 'Causes of poverty in Africa: A review of literature', American International Journal of Social Sciences 3(7), 147-153.

Anger, B., 2010, 'Poverty eradication, millennium development goals and sustainable development in Nigeria', Journal of Sustainable Development 3(4), 138-144. https://doi.org/10.5539/jsd.v3n4p138

Banana, S.C., 1991, Come and share: Introduction to Christian theology, Mambo Press, Gweru.

Banks, W., 1972, The black church in the US: Its origin, growth, contributions, and outlook, Moody Press, Chicago.

Boesak, A.A., 1981, Farewell to innocence, 3rd edn., Orbis, New York.

Bonhoeffer, D., 1967, Letters and papers from prison, SCM, London.

Bonino, J.M., 1984, 'Theology must stop explaining the world and start transforming it', in A.E. McGrath (ed.), Christian theology, p. 105, Blackwell, Oxford.

Branson, N., 2016, Understanding Africa today, Africa Research Institute Briefing Note 1604.

Cataldo, J.W., 2009, A theocratic Yehud? Issues of government in a Persian period, T and T Clark, New York.

Chidoko, C., Sakuhuni, R.C., Dhoro, N.L. \& Gwaindepi, C., 2011, 'Economic determinants of poverty in Zimbabwe', International Journal of Economic Research 2(6), 1-12.

Chilunjika, A. \& Uwizeyimana, D.E., 2015, 'Shifts in the Zimbabwean land reform discourse from 1980 to the present', African Journal of Public Affairs 8(3), 130-143.

Chinake, H., 1997, 'Strategies for poverty alleviation in Zimbabwe', Journal of Social Development in Africa 12(1), 39-51.

Clements, R.E., 1989, 'The messianic expectation in the Old Testament', Journal for the Study of the Old Testament 13(43), 3-19.

Crystal, D., 1990, The Cambridge encyclopedia, Cambridge University Press, Cambridge.

Du Plessis, W.J., 2009, 'Compensation for expropriation under the constitution', PhD dissertation, Stellenbosch University, Stellenbosch, Cape Town.

Gbote, E.Z.M. \& Kgatla, S.T., 2014, 'Prosperity Gospel: A missiological assessment', HTS Theological Studies 70(1), 1-10. https://doi.org/10.4102/hts.v70i1.2105

Gottwald, K.N., 1993, 'Social class as an analytic and hermeneutical category in Biblical Studies', Journal of Biblical Literature 112(1), 3-22. https://doi.org/ $10.2307 / 3267861$

Grubb, N.W. \& Ryan, P., 1999, The roles of evaluation for vocational education and training: Plain talk on the field dreams, ILO, Geneva.

Holmgren, F.C., 1987, Ezra and Nehemiah: Israel alive again, Eerdmans, Grand Rapids, MI. Kamidza, R., 1996, 'What donors want in the budget', SAPES Monthly 1(9), 28-29.

Kankwanda, M., 2002, Poverty eradication: Where Africa stands, Economica, London.

Kiogora, T.G., 1998, 'Black hermeneutics', in S. Maimela \& A. König (eds.), Initiation into theology: The rich variety of theology and hermeneutics, pp. 337-347, JL van Schaik, Pretoria.

Kessler, J., 2007, 'Diaspora and homeland in the early Achaemenid period: Community, geography and demography in Zechariah 1-8', in J.L. Berquist (ed.), Approaching Yehud: New approaches to the study of the Persian period, pp. 137-166, Society of Biblical Literature, Atlanta.
Kriger, N., 2003, Guerrilla veterans in the post-war Zimbabwe: Symbolic and violent politics, 1980-1987, Cambridge University Press, Cambridge.

Kunhiyop, S.W., 2008, African Christian ethics, Word Alive, Nairobi.

Le Roux, J.H., 1996, Woorde van wysheid: Lewenskuns vir elke dag, Christelike Uitgewersmaatskappy, Vereeniging.

Masiiwa, M., 2004, Land reform programme in Zimbabwe: Disparity between policy design and Implementation, Institute of Development Studies, University of Zimbabwe, Harare.

Mbabama, T., 2018, 'Op-ed: Expropriation without compensation - The ANC's next lie', Daily Maverick 16 March, n.p.

Mbeki, T., 2006, State of the Nation Address 2006 of the President of South Africa, 3rd February, Cape Town, viewed 10 April 2019, from http://www.ngopulse.org/ newsflash/2006-state-nation-address-president-south-africa-thabo-mbeki.

Mills, G., 2010, Why is Africa poor?, Center for Global Liberty \& Prosperity: Development Policy Briefing Paper No. 6, pp. 1-8.

Mfaise, Y., 2018, 'On land expropriation without compensation: The constitutional property clause is sufficient to Achieve land reform', AgriSA 1-3.

Narayan, D., Chambers, R., Shah, M.K. \& Petesch, P., 2000, Voices of the poor: Crying out for change, World Bank, Washington, DC.

Ndlovu-Gatsheni, J.S., 2009, 'Making of Mugabeism in local and global politics: "So, Blair, keep your England and I will keep my Zimbabwe",', Third World Quarterly 30(6), 1139-1158. https://doi.org/10.1080/01436590903037424

Phakathi, B., 2018, 'Food security the target of land expropriation without compensation, says Ramaphosa', Business Day, 16 February, n.p.

Rugwiji, T., 2012, Reading the exodus liberation motif from the modern postbiblical world: The Zimbabwean society and the reality of oppression, Lambert Academic Publishing, Saarbrucken.

Rugwiji, T., 2013, 'Appropriating the Judean post-exilic literature in a postcolonial discourse - A case for Zimbabwe', PhD thesis, University of South Africa, Pretoria.

Rugwiji, T., 2017, 'Land, farming and socio-economic development in Yehud: A quest for sustainable development towards poverty reduction in Zimbabwe', Scriptura 116(1), 1-34. https://doi.org/10.7833/116-1-1336

Scheffler, E., 2001, Politics in ancient Israel, Biblia, Pretoria.

Scheffler, E., 2004, 'Jung, the Pentateuch and ethics', Verbum et Ecclesia Jrg 25(2), 653-675. https://doi.org/10.4102/ve.v25i2.292

Scheffler, E., 2011, 'Pleading poverty (or identifying with the poor for selfish reasons): On the ideology of Psalm 109', Old Testament Essays 24(1), 192-207.

Scheffler, E., 2012, 'Poverty in the Book of Proverbs: Looking from above', Scriptura 111(3), 480-496.

Scheffler, E., 2013, 'Of poverty prevention in the Pentateuch as a continuing contemporary challenge', Verbum ET Ecclesia 34 (2), 1-14. https://doi.org/ contemporary challen
$10.4102 / v e . v 34 i 2.869$

Scheffler, E., 2015, 'The poor in the Psalms: A variety of views', Verbum et Ecclesia 36(1), 1-9. https://doi.org/10.4102/ve.v36i1.1478

Sega, D. \& Lekaba, F., 2014, Nigeria's economic boom: A positive outcome for intraAfrica trade, AISA Policy Brief no. 111, pp. 1-5.

Sobrino, J., 1984, 'The poor are the authentic theological source for understanding Christian truth and practice', in A.E. McGrath (ed.), Christian theology, p. 105, Blackwell, Oxford.

Statistics South Africa, 2017, Mid-year population estimates, Statistics SA, Pretoria.

Togarasei, L., 2015, 'Modern/charismatic Pentecostalism as a form of 'religious' secularization in Africa', Studia Historiae Ecclesiasticae 41(1), 56-66. https://doi. org/10.17159/2412-4265/2015/v41n1a5

Turaki, Y., 1997, Tribal gods of Africa, Crossroads Media Service, Jos.

United Nations Human Development, 1998, Human development report, Oxford University Press, New York.

Vanderhooft, D.S., 2000, The Neo-Babylonian Empire and Babylonia in the Latter Prophets, Scholars, Atlanta.

Van der Walt, A.J., 2005, Constitutional property law, Juta \& Co., Cape Town.

Walker, C. \& Cousins, B., 2015, Land divided, land restored: Land reform in South Africa for the 21st century, Jacana, Auckland Park.

Wax, K.P., 2013, 'The intricate relationship between politics and religion in the Hebrew Bible: The prophet Amos as a case study', PhD thesis, Stellenbosch University, Stellenbosch.

Wermter, O., 2005, Politics for everyone and by everyone: A Christian approach, Pauline Publications Africa, Nairobi.

World Bank, 2005, African development indicators 2005, Oxford University Press, New York.

ZHR Rights NGO Forum, 2010, Land reform and property rights in Zimbabwe, ZHR NGO Forum, Harare.

Zimudzi, T.B., 2012, 'Book review. A predicable tragedy: Robert Mugabe and the collapse of Zimbabwe', Journal of Contemporary African Studies 30(3), 508-511. https://doi.org/10.1080/02589001.2012.701847 